Vol. 38(2), pp. 171-191, Dec.2019

ISSN 1821-536X (print)

ISSN 2619-8789 (electronic)
Tanzania Journal of Engineering and Technology Copyright $\odot 2019$ College of Engineering and Technology, University of Dar es Salaam

Full Length Research Paper

\title{
Land Use/Cover Change and their Impacts on Streamflow in Kikuletwa Catchment of Pangani River Basin, Tanzania
}

\author{
Upendo E. Msovu' ${ }^{1 *}$, Deogratias M.M. Mulungu ${ }^{1}$, Joel K. Nobert ${ }^{1}$ and Henry Mahoo ${ }^{2}$ \\ ${ }^{1}$ Department of Water Resources Engineering, College of Engineering and Technology, \\ University of Dar es Salaam, P.O. Box 35131, Dar es Salaam, Tanzania. \\ ${ }^{2}$ Department of Agricultural Engineering, Sokoine University of Agriculture, Morogoro, \\ Tanzania. \\ *Corresponding author: upendoeliuze@yahoo.co.uk
}

\begin{abstract}
Streamflow perturbation is highly prevalent in Kikuletwa catchment. However, little is known concerning land use/cover change (LULCC) with regard to streamflow perturbation in the catchment. This study aims to detect the historical and predict future LULCC and assess their impacts on streamflow amounts using the Soil and Water Assessment Tool (SWAT) model. Supervised classification of Landsat imagery data for 1985, 2000 and 2015 years was done in ERDAS 14 Imagine software. Future prediction of LULCC was done using Module for Land Use Change Evaluation (MOLUSCE) tool, a QGIS plug-in. An accuracy ranging from $79 \%$ to $82 \%$ was obtained for all steps. The results revealed that, from 1985 to 2000; 1985 to 2015; 1985 to 2030 and 1985 to 2050 the percentage of area change in cultivated land is $+21.1 \% ;+29.2 \% ;+38.2 \%$ and $+42.7 \%$, respectively; forest is $2.3 \%,-3.1 \%,-3.8 \%$ and $-5.8 \%$, respectively; and shrubland is $-6.3 \%,-10 \%,-15.7 \%$ and $16 \%$, respectively. The performance of SWAT model during calibration were 0.74, 0.75, 0.51 and $-0.5 \%$ for NSE, R2, RSR and PBIAS, respectively. The impacts of LULCC indicated that, between 1985 to 2000; 1985 to 2015; 1985 to 2030 and 1985 to 2050, the percentage increase in average simulated annual flow is $4.7 \%, 6.8 \%, 12.6 \%$ and $19.3 \%$, respectively. Surface runoff increased from $25.2 \mathrm{~mm}$ (baseline) to $34.5 \mathrm{~mm}$ (36.9\%); $36.2 \mathrm{~mm}$ (42.4\%); $41.4 \mathrm{~mm}(64.3 \%)$ and $47.6 \mathrm{~mm}(88.9 \%)$, respectively. Base flow decreased marginally from $82.2 \mathrm{~mm}$ (baseline) to $79 \mathrm{~mm}$ (-3.8\%); $77.8 \mathrm{~mm}(5.4 \%) ; 75.4 \mathrm{~mm} \mathrm{(-8.3 \% )} \mathrm{and} 73.9 \mathrm{~mm}(-$ $10.1 \%)$, respectively. Thus, apart from climate effects, streamflow perturbation in the catchment is also related to disturbances of catchment influences such as LULCC as revealed in this study. The study is useful for land planners and water resources managers and policy makers in managing resources sustainably.
\end{abstract}

Keywords: ERDAS, Kikuletwa catchment, Land use land cover change, MOLUSCE tool, Streamflow, SWAT model.

\section{INTRODUCTION}

The importance of remote sensing data and hydrological modelling approach using Soil and Water Assessment Tool (SWAT) in analysing Land Use and Land Cover Change (LULCC) impacts on streamflow amounts has been demonstrated in this study. LULCC is considered as one of the drivers of streamflow change as it can cause changes in the hydrological processes of the catchment (Munishi et al., 2009; Amini et al., 2011; Brown et al., 2013; Tan et al., 2014; Chawla and 
Mujumdar, 2015; Guzha et al., 2018). Several researchers have claimed that the main causes of LULCC are population growth, socio-economic development and pressure for agricultural land (Lambin et al. 2001; Lambin et al., 2003; Shaghude, 2006). To understand how LULCC has affected streamflow in the past and how it will affect the future is vital in planning and managing current and future water resources (Mulungu and Kashaigili, 2012; Nobert and Jeremiah, 2012). It is also worth to know the impacts of LULCC on the streamflow and catchment as a whole, which will help land planners and policymakers in decision making for future land use plans and management. Kikuletwa catchment of the Upper Pangani River basin in Tanzania experiences streamflow perturbation, which is highly prevalent. However, little is known concerning LULCC with regard to streamflow perturbation in the catchment.

In some parts of Kikuletwa catchment and Pangani River basin as a whole, investigations on the impacts of LULCC on the hydrology of the catchment have been conducted (e.g. Yanda and Shishira, 1999; Yanda, 2002; Shishira, 2002; Missana et al., 2003; Shaghude, 2006; Yanda and Munishi, 2006; Munishi et al., 2009; Hemp, 2009; Chiwa, 2012). Munishi et al. (2009) investigated the impacts of changes in vegetation cover on dry season flow in the Kikuletwa River in Pangani River Basin, Northern Tanzania and revealed insignificant changes in dry season flow. Hemp (2009) revealed that over the past 70 years, the forest in the upper areas of Mount Kilimanjaro has decreased to about one-third of its original coverage, and the cause was climatedriven fire and land clearing which resulted to the reduction in cloud forests and water yield. According to Hemp (2005) and Hemp (2006), cloud forests are vital for watersheds in assisting filtering, water storage and collecting cloud water or fog.
The hydrological modelling approach using distributed physically-based hydrologic models for quantifying the impacts of LULCC on streamflow is considered as one of the most suitable methods (Khoi and Suetsugi, 2014). Compared to other methods, the hydrological modelling approach quantifies the change and attaching it to a particular cause due to a physical mechanism of the catchment processes (Wei et al., 2013). Statistical techniques lack the physical mechanism of the catchment processes (Li et al., 2009). The experimental catchment approach is a very tedious and expensive method and can hardly be used in large catchments (Lørup et al., 1998). On the other hand, empirical or conceptual models have the limitation that, the parameters used may not be directly linked to the physical conditions of the catchment. In that case, a distributed physically-based hydrological modelling approach was opted in this study. Particularly, the SWAT model was selected because of its efficiency in data handling (Arnold et al., 1998; Gassman et al., 2007), worldwide proven as an effective tool for carrying out investigations on hydrological impacts (Ficklin et al., 2013). In addition, the SWAT model was opted because the tool is freely available and user-friendly.

A number of previous studies on LULCC in the hydrology of the catchment for some parts of the Kikuletwa catchment and Pangani River basin have revealed some limitations. For instance, it was noted that the statistical approaches used to this watershed in the previous studies did not show a scientific linkage of the land-use change and the associated impacts on the hydrology of the rivers. Again, no attempts were made in the previous studies to predict future LULCC and assessing its impacts on streamflow. This is vital for land planners, water resources managers, environmentalists and policymakers in decision making. This study, therefore, 
aims at assessing the impacts of historical and future LULCC on streamflow of the Kikuletwa catchment in Northern Tanzania. Specifically, the study analyses trends in streamflow and rainfall variables, maps historical LULCC, predicts future LULCC in the catchment and assesses the impacts of historical and future LULCC on streamflow.

\section{METHODS AND MATERIALS}

\section{Description of the Study Area}

The Kikuletwa catchment with an area of about $6657 \mathrm{~km}^{2}$, lies between latitudes $3^{\circ} 00^{\prime}$ and $3^{\circ} 30^{\prime}$ ' South and between longitudes $36^{\circ} 30^{\prime}$ and $37^{\circ} 15^{\prime}$ East. It is located in the north-western part of the Pangani River basin found in the Northeast of Tanzania (Figure 1). The Kikuletwa catchment has fifteen major rivers and these are Ngaramtoni, Themi, Usa, Ngarasero, Tengeru, Magdarisho, Malala, Nduruma, Maji ya Chai, Kware, Longoi, Sanya, Karanga, Weruweru and Kikafu which rise on the slopes of Mount Meru and the southern slopes of Mount Kilimanjaro (PBWO/IUCN, 2006). The water users include small-scale subsistence farmers, two cities (Arusha and Moshi), large-scale export/commercial farms, pastoralists, miners and tourist facilities. The altitude rises from $670 \mathrm{~m}$ to $5,895 \mathrm{~m}$ above mean sea level whereby the Mount Kilimanjaro summit (Kibo) is the highest point and the lowest point is found in Kikuletwa catchment at the outlet of Kikuletwa River to the Nyumba ya Mungu Reservoir. The long rainfall season (Masika) starts from mid-March to the end of May, while the short rainfall season (Vuli) starts from mid-October to the end of December. The highest rainfall which varies from 1000 to $2500 \mathrm{~mm} /$ year, appears in the highlands, southern mountain slopes of Mount Kilimanjaro and Meru. In the lowlands, annual rainfall is commonly between 300 to $600 \mathrm{~mm} / \mathrm{year}$ (PBWO/IUCN, 2008).

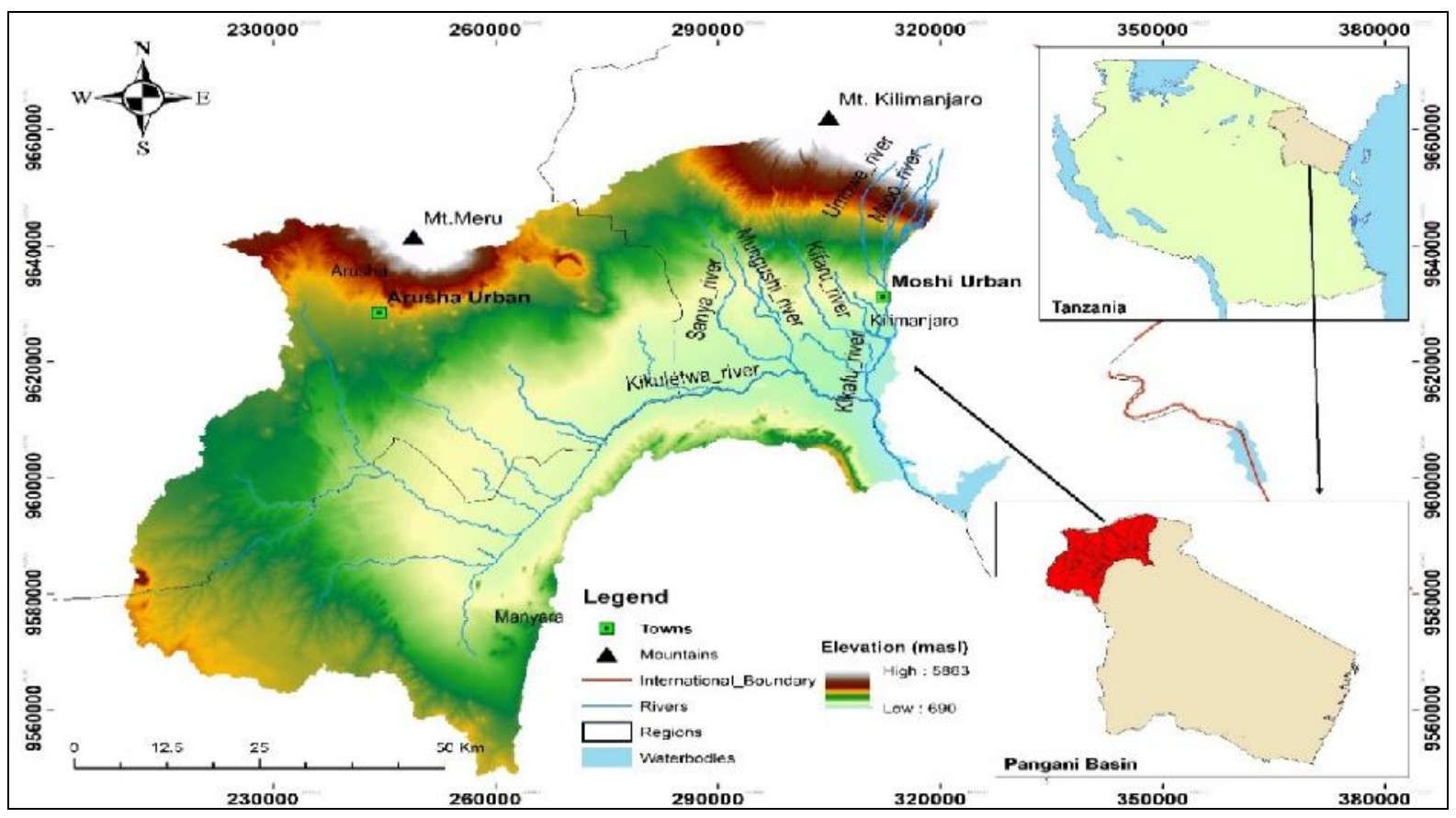

Figure 1: The Kikuletwa catchment and its location in the Pangani River basin 


\section{SWAT model description}

The SWAT model is a distributed, physically-based, continuous-time and comprehensive hydrologic model that operates on a daily time-step basis. The model was developed for predicting the impacts of climate change and land management practices on water, sediments and agricultural chemical yield (Arnold $e t$ al., 1998). It is a very robust scientific tool that provides good estimates. In the SWAT model, the watershed or basin is divided into sub-basins or sub-watersheds which are further divided more into homogenous small units called Hydrological Response Units (HRUs) (Neitsch et al., 2002). The HRUs have unique soils, land use/cover and management practices within the subbasin.

Non-spatial representation of the HRUs within each sub-basin is a major limitation of the SWAT model (Gassman et al., 2007). This does not allow the model to provide a clear spatial representative of the riparian buffer zone, wetlands, etc. In addition, the SWAT model needs a wide range of different data to run the model, and many parameters required to be changed during the calibration process, which makes the calibration exercise to be very tedious. To the local context, the challenges experienced in this study were the presence of rainfall gauging stations in the catchment which are not spatially distributed and with many missing (gaps) data. To overcome this, the study considered the period of calibration which was having a few missing data. However, the SWAT model has been successively applied in Tanzania for instance, experience from Mulungu and Munishi (2007); Ndomba et al. (2008) and Nobert and Jeremiah, (2012).

\section{Data Requirements}

The hydrologic model used, required both spatial and hydro-meteorological datasets.

\section{Hydro-meteorological data}

Rainfall, maximum and minimum temperature, relative humidity, solar radiation, and wind speed were used as climatic data input to the SWAT model. Streamflow data used for SWAT model calibration and validation were collected from the station located at the outlet and downstream of the catchment namely Kikuletwa at TPC (station IDD1). The station is located at latitude $-3.53^{\circ}$ and longitude $37.33^{\circ}$ and has streamflow data from year 1952 to 2015 . In addition to station IDD1, stations IDD20A (at the upstream of the catchment) and IDD55 (at the middle) were used in analysing streamflow trends in the catchment. The climate and streamflow data on a daily time-step basis were obtained from the Ministry of Water Tanzania (Pangani Basin Water Office at Moshi), Tanzania Meteorological Agency (TMA) and the Department of Water Resources Engineering of the University of Dar es Salaam (UDSM). Table 1 shows the rainfall stations used in the study.

\section{Spatial or grid data}

Soil map, land use map, Digital Elevation Model (DEM) and stream network were used as spatial input data to the SWAT model. The stream network was digitized from the Kikuletwa Topographic Sheets. Topographic sheets of 1:50,000 scale covering the study area were collected from the Ministry of Land and Settlements, soil map was from Food and Agriculture Organization (FAO) and the DEM of 30 m resolution, was from Shuttle Radar Topography Mission (SRTM). Table 2 shows some of the inventory of spatial or grid data that were used in SWAT modelling. 
Table 1: Inventory of selected rainfall stations in the study area

\begin{tabular}{|c|c|c|c|c|c|c|}
\hline S/N & $\begin{array}{c}\text { Station } \\
\text { Code }\end{array}$ & Latitude & Longitude & $\begin{array}{c}\text { Available } \\
\text { records }\end{array}$ & $\begin{array}{c}\text { Common } \\
\text { period }\end{array}$ & $\begin{array}{c}\text { \% of } \\
\text { Missing }\end{array}$ \\
\hline 1 & 09336001 & -3.58 & 36.68 & $1922-2015$ & $1971-1985$ & 6.8 \\
\hline 2 & 09336013 & -3.40 & 36.70 & $1935-2005$ & $1971-1985$ & 0.00 \\
\hline 3 & 09336015 & -3.42 & 36.86 & $1942-1998$ & $1971-1985$ & 1.13 \\
\hline 4 & 09336031 & -3.33 & 36.62 & $1955-1995$ & $1971-1985$ & 0.31 \\
\hline 5 & 09336033 & -3.37 & 36.63 & $1947-2015$ & $1971-1985$ & 0.00 \\
\hline 6 & 09336045 & -3.38 & 36.87 & $1971-2005$ & $1971-1985$ & 13.34 \\
\hline 7 & 09337004 & -3.35 & 37.33 & $1929-2015$ & $1971-1985$ & 0.01 \\
\hline 8 & 09337021 & -3.23 & 37.25 & $1935-2015$ & $1971-1985$ & 0.04 \\
\hline 9 & 09337028 & -3.53 & 37.33 & $1938-2011$ & $1971-1985$ & 0.00 \\
\hline 10 & 09337078 & -3.19 & 37.10 & $1954-2004$ & $1971-1985$ & 6.70 \\
\hline 11 & 09337091 & -3.34 & 37.34 & $1960-2015$ & $1971-1985$ & 0.15 \\
\hline 12 & 09337115 & -3.42 & 37.07 & $1971-2015$ & $1971-1985$ & 0.49 \\
\hline
\end{tabular}

Table 2: Inventory of spatial or grid data used in the study

\begin{tabular}{|l|l|l|}
\hline Data & Source & Year \\
\hline DEM 30 resolution & Shuttle Rada Topography Mission & 2014 \\
\hline LULC map 30 resolution & United States Geological Survey & $1985,2000,2015$ \\
\hline Soil map & Food and Agriculture Organization & 1995 \\
\hline Stream network & Digitized from Kikuletwa Topo sheets & 1985 \\
\hline
\end{tabular}

\section{Satellite data acquisition and processing}

The selected Landsat TM Satellite images of $30 \mathrm{~m}$ resolution for the years 1985 , 2000 and 2015 were downloaded from the United States Geological Survey (USGS) Earth Explorer website accessed at http://earthexplorer.usgs.gov/. The selected date for data acquisition for this study is mainly due to the availability of cloud-free images and observation of the hydrological year. To the downloaded satellite images, the radiometric and atmospheric correction was performed. The images were processed to top of atmosphere reflectance by using the radiometric correction tool and F-mask tool in ENVI software. Table 3 shows the Landsat Satellite imagery used in the study.

\section{Ground truth survey data collection}

A field survey was conducted at the study area in August 2018 (dry season) to get useful information used for the classification of satellite images and for accuracy assessment. To the processed satellite images, a simple random sampling strategy (Stehman, 2009) was used to select the sampling point. Forty (40) sampling points were taken for groups of LULC that were dominant and highly variable and; the sampling points were reduced for less dominant and variable LULC groups (Stehman, 2009). In that case, a total of 205 sampling points with doubtful LULC types were carefully randomly selected from the satellite image. 
The sampling points were then positioned on a very high resolution google earth map to correctly pinpoint them on the ground. On google earth map, the identified points were then located on the ground by the aid of Etrex Garmin GPS and Samsung tablet with Locus map application to collect spatial LULC representation. Similarly,
Topographic sheets covering the study area were also used for providing ground truth information. The collected information was used to recognize the LULC on the satellite image to enhance classification processes and for accuracy assessment of the classified LULC.

Table 3: Landsat Satellite imagery used for change detection analysis

\begin{tabular}{|l|l|l|l|l|}
\hline \multicolumn{1}{|c|}{ Area } & Path & Row & \multicolumn{1}{c|}{ Image type/Sensor } & \multicolumn{1}{c|}{ Date } \\
\hline Scene 1 & 168 & 062 & Landsat 5 (MSS-TM) & $17 / 12 / 1985$ \\
\hline Scene 2 & 168 & 063 & Landsat 5 (MSS-TM) & $17 / 12 / 1985$ \\
\hline Scene 1 & 168 & 062 & Landsat 7 (ETM+SLC) & $21 / 02 / 2000$ \\
\hline Scene 2 & 168 & 063 & Landsat 7 (ETM+SLC) & $21 / 02 / 2000$ \\
\hline Scene 1 & 168 & 062 & Landsat 8 (OLI-TIRS) & $21 / 12 / 2015$ \\
\hline Scene 2 & 168 & 063 & Landsat 8 (OLI-TIRS) & $21 / 12 / 2015$ \\
\hline
\end{tabular}

Trend Analysis in Streamflow and Rainfall Data

To understand the influence of LULCC on the streamflow perturbation, the trends in rainfall and streamflow variables were conducted. The common period ranges from 1980 to 2015 to cover the LULC maps period used for assessing the impacts

$$
\begin{gathered}
S=\sum_{i=1}^{n-1} \sum_{j=i+1}^{n} \operatorname{sgn}\left(x_{j}-x_{i}\right) \\
\operatorname{sgn}\left(x_{j}-x_{i}\right)=\left\{\begin{array}{l}
1 \text { if } x_{j}>x_{i} \\
0 \text { if } x_{j}=x_{i} \\
-1 \text { if } x_{j}<x_{i}
\end{array} \quad \ldots .\right.
\end{gathered}
$$

Where $\mathrm{S}$ is defined as total sgn (sign) of the whole time series, sgn is defined as shown by equation (2) and is used to count the difference between two values $x_{i}$ and $x_{j}$ which are the sequential data values and $\mathrm{n}$ is the total number of the recorded data in the time series. The Mann-Kendall statistic test $\mathrm{S}$-statistic and its variance $\operatorname{Var}(\mathrm{S})$ were used to calculate a standard normal variate $Z$, at the $95 \%$ confidence level $(|(Z)|>1.96) . \quad Z$ is used in of historical LULCC on streamflow. Mann-Kendall test was used for detecting the presence or absence of trends in linear and nonlinear time series data. Mann (1945) and Kendall (1975) is a nonparametric (distribution-free) rankbased test. Mann-Kendall statistic $\mathrm{S}$ is given by equation (1).

assessing whether the trend is significant or not significant.

\section{Historical Land Use and Cover Change Detection}

\section{Image classification, accuracy assessment and validation}

Field survey reference data collected, google earth and Topographic maps covering the study area, were used for 
creating training samples. Supervised classification was done using the Maximum Likelihood Classifier algorithm approach in ERDAS Imagine 2014 software. Eight LULC types were considered and included ice cover, bare land, shrubland, cultivated land, forest, grassland, built-up areas, and water bodies. After classification, accuracy assessment was conducted. ArcMap and Excel software were used to perform the accuracy assessment. Topographical sheets for the year 1990 covering the study area, Tanzania LULC map of 1996 from Institute of Resource Assessment of UDSM and high resolution 2015 google earth images were used to validate developed land use for years 1985, 2000 and 2015.

\section{Change detection analysis of land use land cover}

In this study, the post-classification comparison method (Lu and Weng, 2007) was conducted to analyse LULCC for various land use/cover types independently from classified images of 1985, 2005 and 2015. This was done by using a combined tool in ArcGIS. Figure 2 shows the procedures followed for LULC classification and change detection.

\section{Future Land Change Prediction Under Business-as-usual Scenario}

Developed LULC maps for the years 2000 and 2015 were used to predict the future LULC images of 2030 and 2050 using the MOLUSCE tool, a QGIS plug-in. Prediction of land cover change was done by Artificial Neutral Network (ANN) and Markov Chain- Cellular Automata, based built-in module of the MOLUCSE tool. The principle behind the business-as-usual scenario is to evaluate the trend of change from one land-use system category to another. The simulation variables or influencing factors in this study were a distance to road, slope and elevation map to predict the future land use categories pattern based on the previous past change trend.

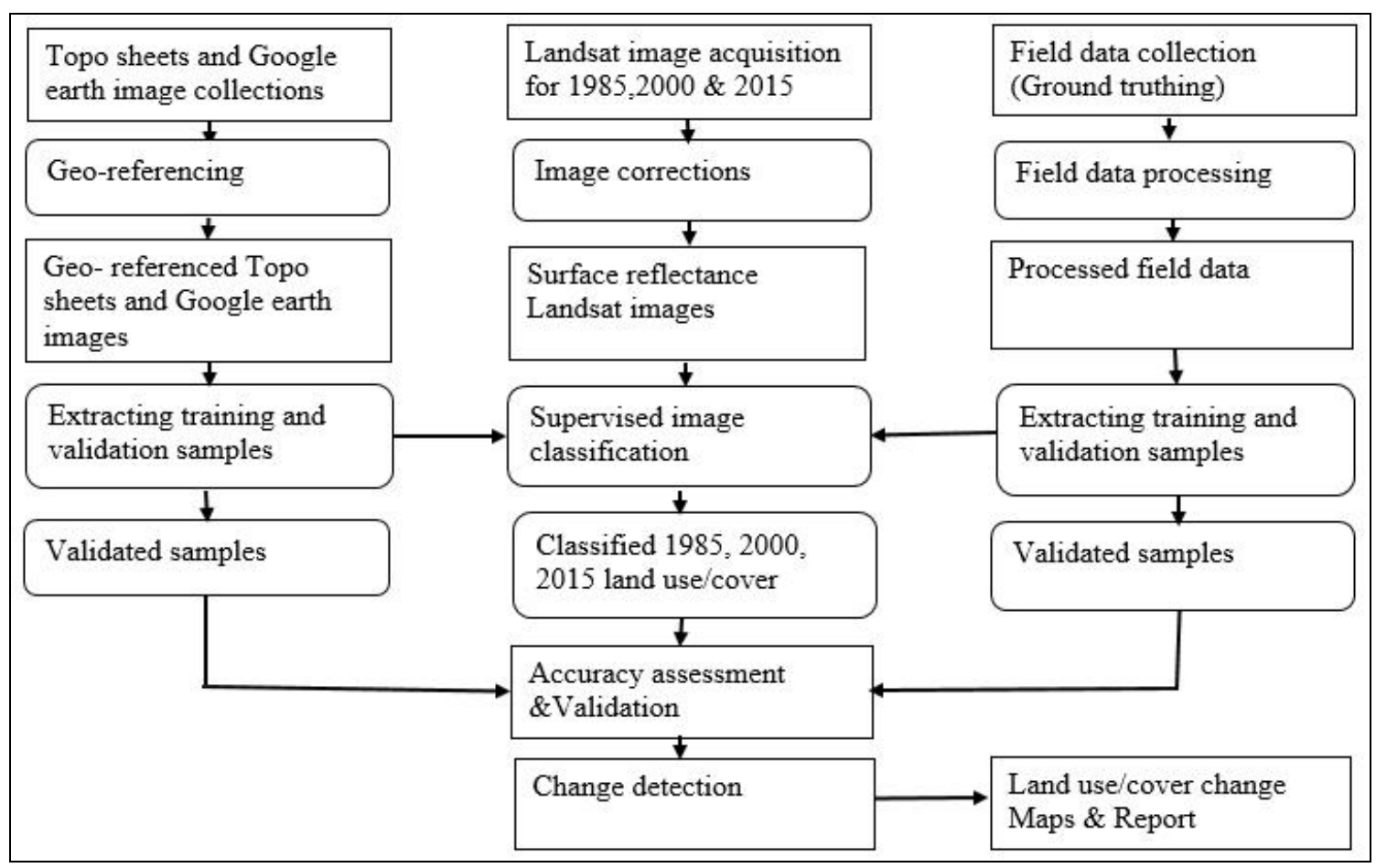

Figure 2: Methodological Flowchart for the Classification of Satellite Imagery and Change Detection 
Land Use/Cover Change and their Impacts on Streamflow in Kikuletwa Catchment of Pangani River Basin, Tanzania

A DEM of $30 \mathrm{~m}$ from Shuttle Radar Topography Mission (SRTM) data was used for creating slope and elevation maps. A road network map was prepared from topographical sheets of the study area and verified using a high-resolution Google earth map of 2015 in ArcGIS. Before the prediction of future LULC, validation of the MOLUSCE tool to perform future prediction was performed. This was done by using the LULC maps for the years 1985 and 2000 to predict the land use/cover for the year 2015. The predicted LULC map for 2015 was then compared with LULC, which was classified from Landsat images of 2015. The accuracy obtained was good enough for the MOLUSCE to be used for predicting 2030 and 2050 future land use. Figure 3 shows the methodological flow chart for future land use /cover and LULCC prediction.

\section{Assessing Land Use/Cover Change Impacts on Streamflow Using SWAT Model}

\section{Model set up}

The model set up was carried in the QSWAT interface. The latest QSWAT version 1.3 which uses the 2012 version of the SWAT model was downloaded from the SWAT website http://swat.tamu.edu/. After delineation of a watershed, an overlay of the three datasets i.e. land use/cover map, soil map and slope/DEM was done for HRUs creation. Climatic /weather station and weather generator files were loaded. Then water use, Rundugai natural springs modelled as a point source, were edited and files were written. The period of the simulation was from 1971 to 1985 . Figure 4 presents the delineated Kikuletwa catchment.

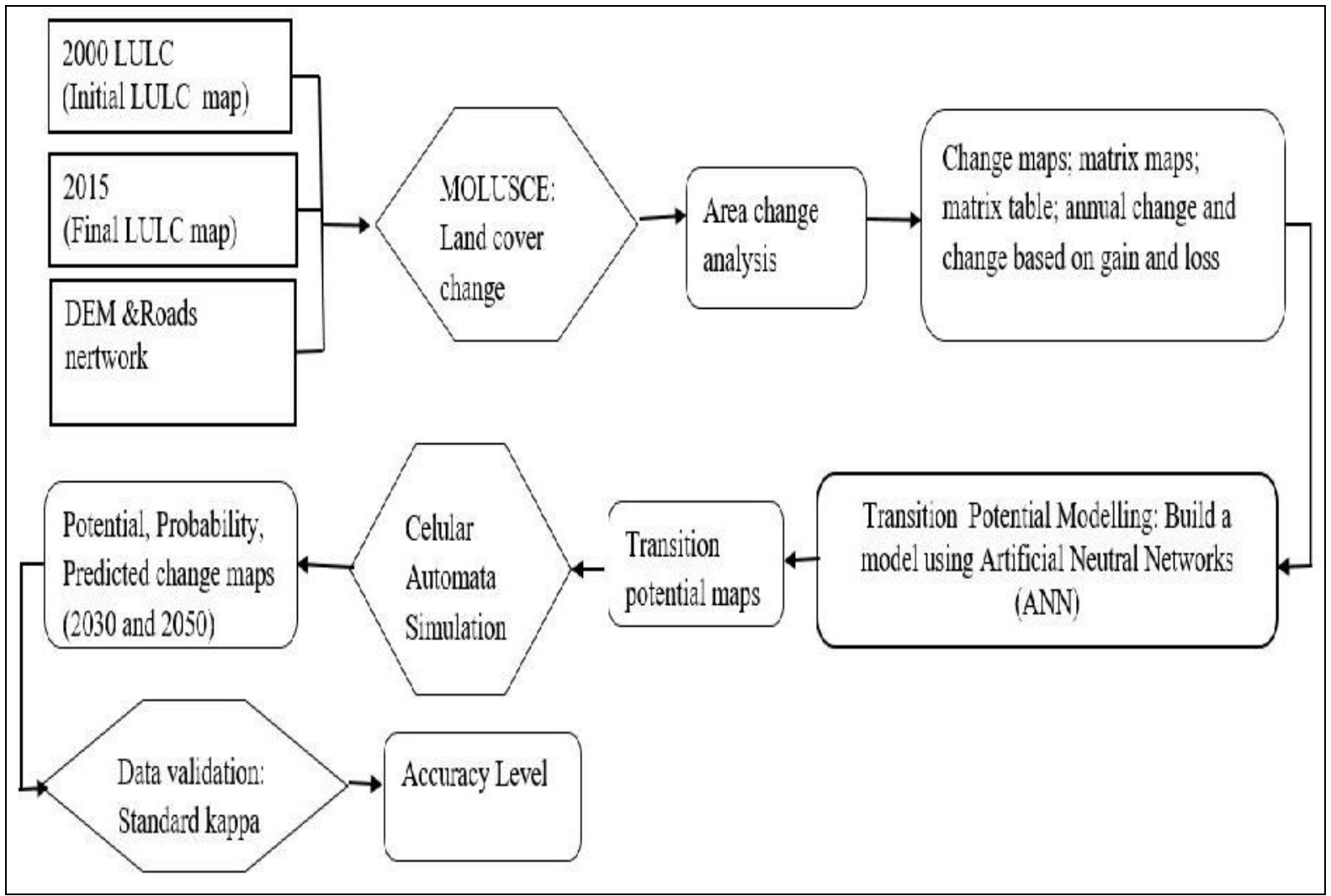

Figure 3: Methodological Flowchart for Future Land Use Land Cover Prediction 


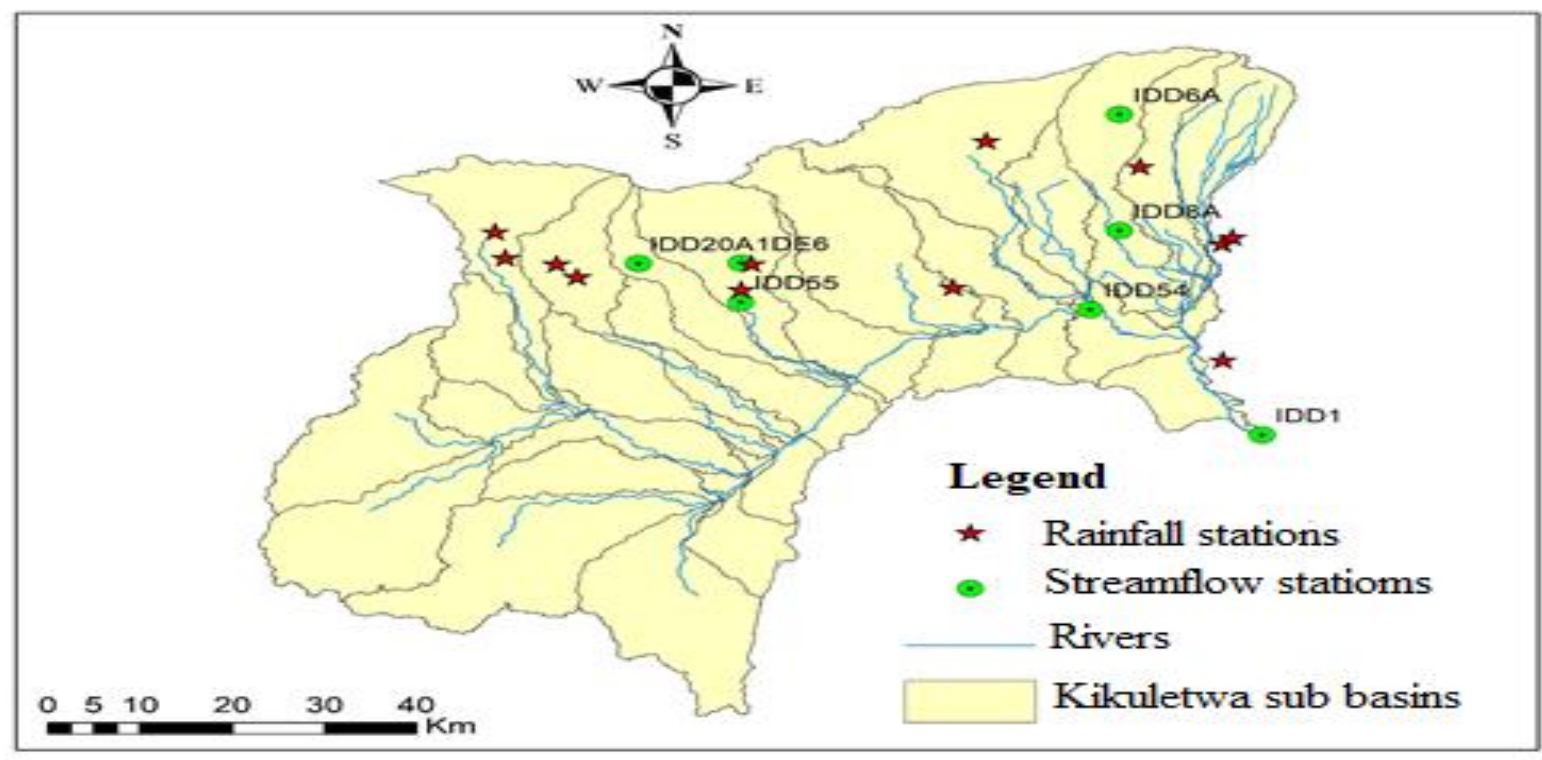

Figure 4: Delineated Kikuletwa Catchment

\section{Model calibration and sensitivity analysis}

The separation between actual base flow and direct or surface flow in the catchment was done by Web-based Hydrograph Analysis Tool (WHAT) using the observed streamflow measured data at the outlet of the catchment. The auto-calibration using SWAT- CUP software was done for parameter optimization as well as recognizing sensitive parameters that govern the hydrological processes of a watershed. Then the calibration process continued by adjusting parameters manually until the simulated and observed value displayed a good fit as per model performance criteria.

\section{Model performance evaluation}

The statistical guidelines for evaluating the performance of the model in this study were those proposed by Moriasi et al. (2007). These included the Nash-Sutcliffe efficiency (NSE), percent bias (PBIAS), a ratio of the root mean square error to the standard deviation of measured data (RSR) and Coefficient of determination $\left(\mathrm{R}^{2}\right)$. The efficiency of the SWAT model is considered satisfactory or acceptable when performance rating of NSE $>0.5, \mathrm{R}^{2}>0.5$, PBIAS $< \pm 25 \%$ and RSR $<0.7$ are met during calibration and validation period. When NSE values are $\geq 65 \%$ for both periods, the model is considered as 'good'.

\section{Implementing the SWAT model for assessing land use/cover change impacts on streamflow}

The calibrated and validated SWAT model was run using the developed five scenarios of LULCC. The first scenario was the baseline scenario, where the model was ran using the 1985 LULC map and climate data from 1971 to 1985 as used in a model set up, calibration and validation stages. For the second to fifth scenarios, other components of the model such as weather data and soil were kept constant and the model was run using land use maps for the years 2000, 2015, 2030 and 2050; one by one as indicated in Figure 5. The results were compared to the baseline scenarios to assess the impact of land use/cover change. The assessed and compared hydrological components were streamflow, surface runoff, groundwater (baseflow), high flow (Q5) and low flow (Q95) indices from Flow Duration Curves (FDCs). 
Land Use/Cover Change and their Impacts on Streamflow in Kikuletwa Catchment of Pangani River Basin, Tanzania

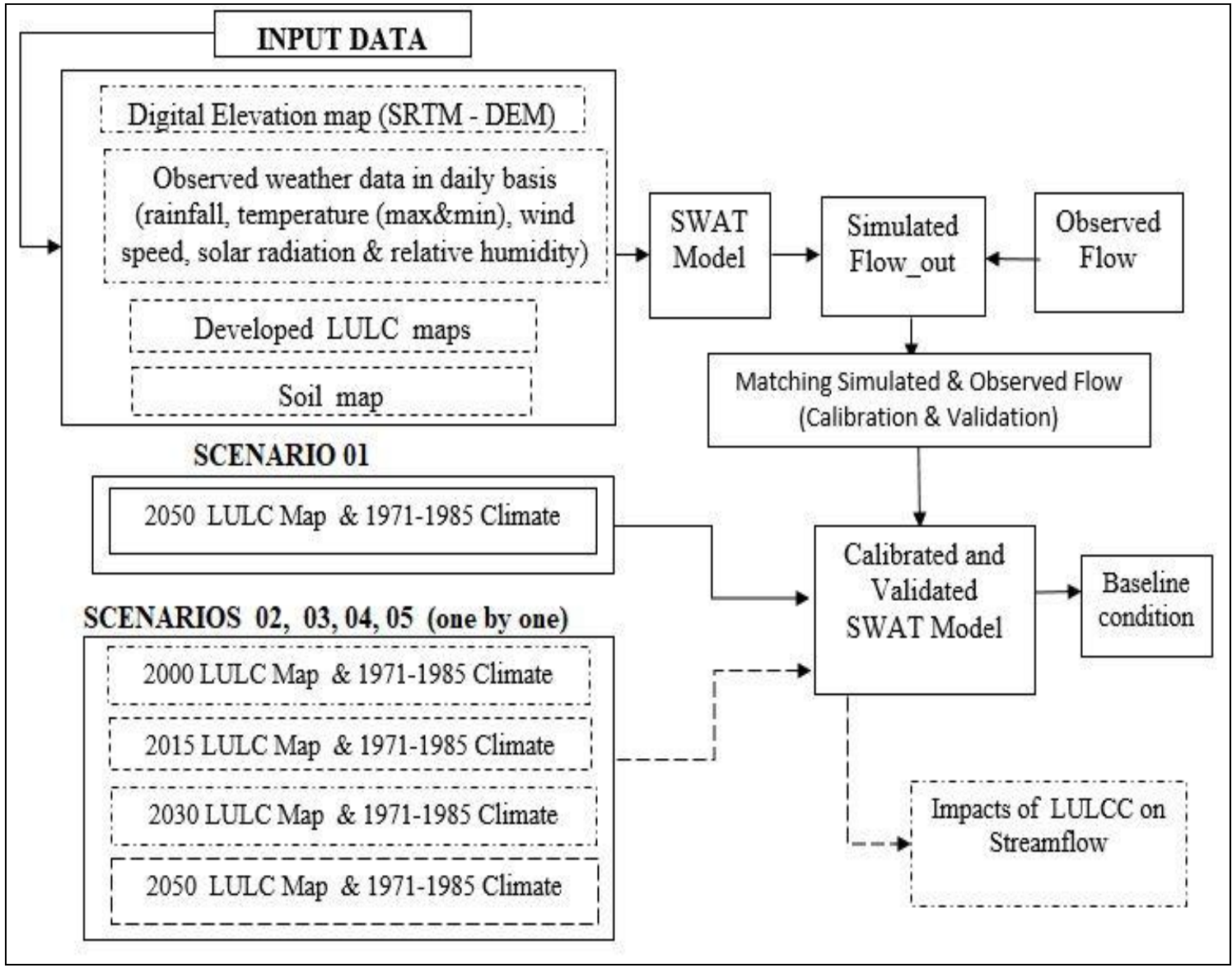

Figure 5: Methodological Flowchart for LULCC Impacts analysis using SWAT

\section{RESULTS AND DISCUSSION}

\section{Trend Analysis of Streamflow and Rainfall}

\section{Rainfall changes}

The results of the total annual and seasonal rainfall in the catchment showed a decreasing trend for most of the analysed stations in the upstream and downstream of the catchment from year 1980 to 2015 . The Mann-Kendall statistic $Z_{\mathrm{s}}$ value for total annual and seasonal rainfall in the study area at the $95 \%$ confidence level $(\mathrm{I}(\mathrm{Z}) \mid>1.96)$ and a significant trend in bold is presented in Tables 4 and 5.
From these Tables, the observations show that most of the stations indicated a decreasing trend in rainfall in the catchment though not significant to all stations. These results are similar to the findings from previous studies (e.g. Hemp, 2005; IPCC, 2007; Munishi and Sawere, 2014; Lalika et al., 2014).

\section{Streamflow changes}

The results of the trend analysis show that streamflow decreased with time. Table 6 shows a trend in average annual flow while Table 7 shows a trend in the seasonal average flow from year 1980 to 2015 at the $95 \%$ confidence level $(|(Z)|>1.96)$ and a significant trend in bold. 
Table 4: Mann-Kendall statistic $Z_{s}$ value for total annual precipitation

\begin{tabular}{|l|l|l|l|l|}
\hline Station & 09336000 & 09336001 & 09336014 & 09336033 \\
\hline Test statistic $\mathbf{Z}_{\mathbf{s}}$ & $\mathbf{- 3 . 2 2}$ & $\mathbf{- 2 . 6 8}$ & -0.77 & -0.67 \\
\hline Station & 09337091 & 09337115 & 09337004 & 09337021 \\
\hline Test statistic $\mathbf{Z}_{\mathbf{s}}$ & -1.93 & -0.53 & -1.78 & -1.21 \\
\hline
\end{tabular}

Table 5: Mann-Kendall statistic $\mathrm{Z}_{\mathrm{s}}$ value for seasonal precipitation

\begin{tabular}{|c|c|c|c|c|c|c|}
\hline \multirow{2}{*}{ S/N } & Station & Test Parameter & \multicolumn{4}{|c|}{ Seasons } \\
\cline { 4 - 7 } & & & JF & MAM & JJAS & OND \\
\hline 1 & 09336000 & Test statistic $Z_{\mathrm{s}}$ & -0.97 & -1.54 & -0.99 & $\mathbf{- 2 . 7 6}$ \\
\hline 2 & 09336001 & Test statistic $Z_{\mathrm{s}}$ & -0.14 & $-\mathbf{- 2 . 2 9}$ & -0.04 & -0.53 \\
\hline 3 & 09336014 & Test statistic $Z_{\mathrm{s}}$ & -0.06 & -1.23 & $\mathbf{- 3 . 1 0}$ & -0.16 \\
\hline 4 & 09336033 & Test statistic $Z_{\mathrm{s}}$ & 0.80 & -0.20 & -1.33 & -0.27 \\
\hline 5 & 09337004 & Test statistic $Z_{\mathrm{s}}$ & 0.23 & -1.59 & -1.81 & -0.86 \\
\hline 6 & 09337021 & Test statistic $Z_{\mathrm{s}}$ & -0.19 & -1.10 & -1.40 & -0.42 \\
\hline 7 & 09337091 & Test statistic $Z_{\mathrm{s}}$ & -0.64 & -1.73 & $\mathbf{- 2 . 4 3}$ & -1.67 \\
\hline 8 & 09337115 & Test statistic $Z_{\mathrm{s}}$ & 0.50 & -0.05 & -1.73 & -0.63 \\
\hline
\end{tabular}

Table 6: Mann-Kendall statistic $Z_{s}$ value for the average annual flow

\begin{tabular}{|c|l|c|c|l|}
\hline S/N & Station & Test parameter & Mean annual flow & Remarks \\
\hline 1 & IDD1 & Test statistic $Z_{s}$ & $\mathbf{- 2 . 5 2}$ & Significant \\
\hline 2 & IDD55 & Test statistic $Z_{s}$ & $-\mathbf{1 . 9 9}$ & Significant \\
\hline 3 & IDD20A & Test statistic $Z_{s}$ & -0.02 & Insignificant \\
\hline
\end{tabular}

Table 7: Mann-Kendall statistic $Z_{s}$ value for seasonal average low and high flows

\begin{tabular}{|c|l|l|l|l|l|l|}
\hline S/N & \multirow{2}{*}{ Station } & Test parameter & \multicolumn{2}{|c|}{ Season } & \multicolumn{2}{|c|}{ Season } \\
\cline { 3 - 7 } & & & FM & Remarks & AMJ & Remarks \\
\hline 1 & IDD1 & Test statistic $Z_{s}$ & $\mathbf{- 2 . 1 0}$ & Significant & $\mathbf{- 4 . 7 2}$ & Significant \\
\hline 2 & IDD55 & Test statistic $Z_{s}$ & -1.59 & Insignificant & -1.66 & Insignificant \\
\hline 3 & IDD20A & Test statistic $Z_{s}$ & 0.62 & Insignificant & -0.02 & Insignificant \\
\hline
\end{tabular}

From Table 6 and Table 7, the average annual flow from year 1980 to 2015 decreased significantly at stations IDD1 and IDD55 with $\mathrm{Z}$ values of -2.52 and 1.99 respectively. Low flow seasons (February to March -FM) indicated insignificant decreasing with $\mathrm{Z}$ values of -1.59 at station 1DD55 while a significant decreasing trend was indicated at station IDD1 with Z values of -2.1. High flow season (AprilMay- June - AMJ) indicated a significantly decreasing trend at station IDD1 with the $\mathrm{Z}$ value of -4.72 . The decreasing trend in mean annual streamflow at Kikuletwa catchment from this study is similar to other previous findings (e.g. Lalika et al., 2014; Munishi and Sawere, 2014). 
The reason for the decrease in the flow in this study could be associated with the decrease in rainfall as revealed in Tables 4 and 5 and human activities (e.g. LULLC and water withdrawals). Previous studies conducted in the past at the study area (e.g. Sarmett and Faraji, 1991; Røhr and Killingtveit, 2002; Ngana, 2002; Valimba, 2008 and Munishi et al., 2009) indicated inconsistency change, no change or insignificant changes in low flow season at the stations (IDD1 and IDD54) located below the Rundugai natural springs. This could be attributed to high rainfall in the past, which is vital for groundwater recharge which then contributes to streamflow during the dry season. Also, in the past, having a low population, human activities were not that intense to lead to environmental degradation. With increased population, human activities became much intense leading to environmental degradation with negative effects on water resources. For example, deforestation or a decrease in vegetation cover increases surface runoff and a decrease in the base flow, which is vital during the dry season
(Nobert and Jeremiah, 2012; Tan et al., 2014). Not only that, but intense irrigated agriculture could also be the source of a decrease in the flow in the dry season. On the other hand, trend analysis of high flow index (Q5) and low flow index (95) at station IDD1 (located at the outlet of the catchment); indicated an insignificant decreasing trend.

\section{Land Use /Land Cover Change Analysis}

\section{Historical and projected future land use/cover maps}

The output of developed land use maps for the years 1985, 2000, 2015, and predicted land use maps for 2030 and 2050 are presented in Figure 6 and Table 8 . The overall accuracy of classification for the analysis was $80 \%, 79 \%$, and $81 \%$ for the years 1985, 2000 and 2015 land cover classification, respectively. For future projection, an accuracy of $79 \%$ was obtained for the years 2030 and 2050 land use/cover map.

Table 8: Land use/cover types developed and coverage areas in (ha and \%)

\begin{tabular}{|l|c|c|c|c|c|c|c|c|c|c|}
\hline Year & \multicolumn{2}{|c|}{$\mathbf{1 9 8 5}$} & \multicolumn{2}{c|}{$\mathbf{2 0 0 0}$} & \multicolumn{2}{c|}{$\mathbf{2 0 1 5}$} & \multicolumn{2}{c|}{$\mathbf{2 0 3 0}$} & \multicolumn{2}{|c|}{$\mathbf{2 0 5 0}$} \\
\hline LULC type & $\mathbf{H a}$ & $\mathbf{\%}$ & $\mathbf{H a}$ & $\mathbf{\%}$ & $\mathbf{H a}$ & $\mathbf{\%}$ & $\mathbf{H a}$ & $\mathbf{\%}$ & Ha & \% \\
\hline Ice cover & 536 & 0.08 & 284 & 0.04 & 194 & 0.03 & 37 & 0.01 & 32 & 0.01 \\
\hline Bare land & 1598 & 0.25 & 13282 & 2.08 & 8137 & 1.28 & 11609 & 1.82 & 11213 & 1.76 \\
\hline Shrubs & 224976 & 35.28 & 184601 & 28.94 & 165721 & 25.9 & 126607 & 19.9 & 123840 & 19.4 \\
\hline Cultivated & 127443 & 19.98 & 262293 & 41.13 & 310371 & 48.7 & 369000 & 57.9 & 399680 & 62.7 \\
\hline Forest & 72143 & 11.31 & 57411 & 9.00 & 54467 & 8.54 & 48077 & 7.54 & 35123 & 5.51 \\
\hline Grassland & 209857 & 32.90 & 116536 & 18.27 & 94387 & 14.8 & 77404 & 12.1 & 61773 & 9.69 \\
\hline Built up & 627 & 0.10 & 2917 & 0.46 & 4143 & 0.65 & 4750 & 0.74 & 5857 & 0.92 \\
\hline Water & 592 & 0.09 & 448 & 0.07 & 352 & 0.06 & 284 & 0.04 & 254 & 0.04 \\
\hline Total & 63772 & 100 & 63772 & 100 & 63772 & 100 & 63772 & 100 & 63772 & 100 \\
\hline
\end{tabular}

\section{Historical and future land change detection}

Cultivated land and built areas increased from the past and are expected to increase in the future in order to sustain the rapid increase in population for food and housings. IPCC ( 2001) under scenario A2, predicted an increase in population in the future. Forest, shrubland, and grassland have been transformed into cultivated land and built-up areas. The reason for ice cover decrease at the top of Mount Kilimanjaro could be due to a significant increase in temperature in the study area as revealed by previous studies (e.g. Hemp, 2005; Lalika et al., 2014; Munishi and Sawere, 2014). Water bodies could have 
decreased due to environmental degradation for instance clearing of the forest using fire, which resulted in the reduction in cloud forests and water yield (Hemp, 2009). According to Hemp (2005) and Hemp (2006), cloud forests are vital for watersheds in assisting filtering, water storage and collecting cloud water or fog. Figure 7 shows the percentage area change of LULC.

\section{SWAT Model Calibration and Validation}

Model calibration and validation periods were from year 1976 to 1979 and year 1981 to 1984 respectively. Global sensitivity analysis showed 15 very sensitive parameters governing hydrological processes in the catchment which ranked to most sensitive and included (1) SCS runoff curve number (CN2), (2) Slope length for lateral subsurface flow (SLSOIL), (3) Initial depth of water in the shallow aquifer (SHALLST), (4) Groundwater delay (GW_DELAY) and other 11. Table 9 shows the actual and simulated average annual total water yield, surface runoff, and baseflow. On the other hand; Figure 8 and Figure 9 show the observed and simulated daily flow at station IDD1 used for calibration and validation, respectively. The statistical performance results during calibration were $0.74,0.75,0.51$ and $-0.5 \%$ for NSE, $\mathrm{R}^{2}$, RSR and PBIAS, respectively and; for validation were $0.73,0.78,0.52$ and $-0.8 \%$ for NSE, $\mathrm{R}^{2}$, RSR and PBIAS, respectively.

From Figures 8 and 9 it can be observed that the model underestimated high peaks as it could not capture the high peaks. One reason could be extreme events for example year 1979 floods whereby the SWAT model failed to capture the simulated high peaks. The failure of the SWAT model to capture extreme events was also revealed by other researchers (Tan et al., 2014) who suggested that the occurrence of extreme floods during early 1984 in the Johr River basin in Malaysia could be the reason for poor capture of the high peak from the SWAT model. However, according to performance rating criteria by Moriasi et al. (2007), the calibrated and validated SWAT model in this study is considered as 'good' for assessing the impacts of LULCC on streamflow. 
Land Use/Cover Change and their Impacts on Streamflow in Kikuletwa Catchment of Pangani River Basin, Tanzania

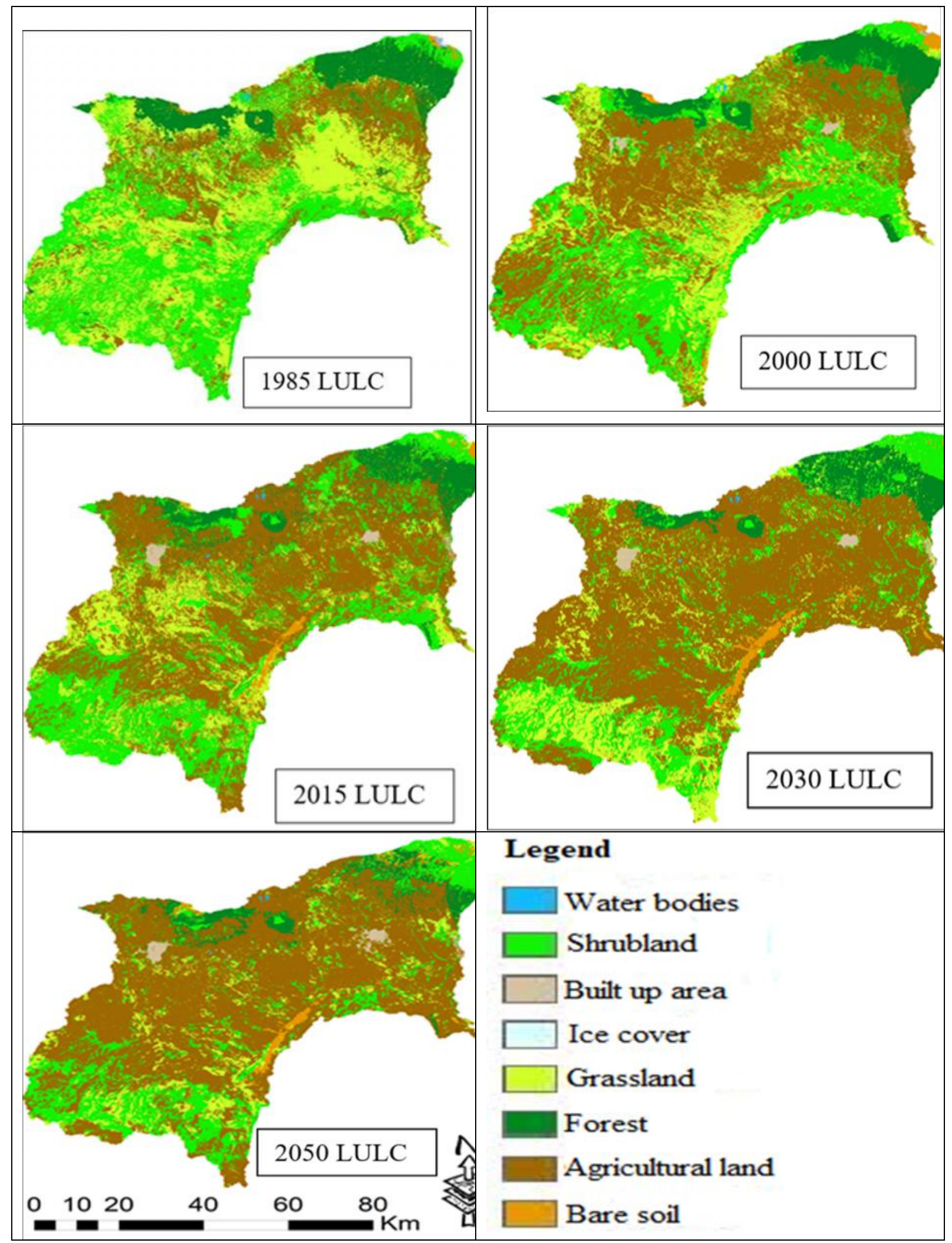

Figure 6: Developed LULC maps for the year 1985, 2000, 2015, 2030 and 2050 


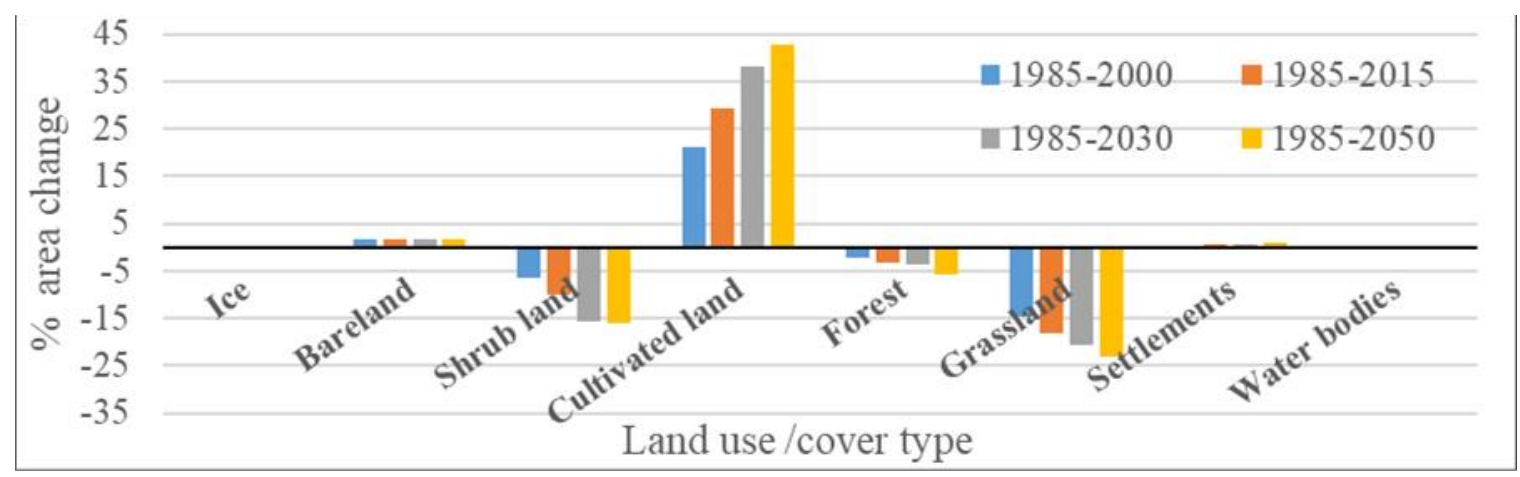

Figure 7: Percentage area change of land use/cover for the specified period

Table 9: Actual and simulated surface or direct runoff and baseflow separation

\begin{tabular}{|l|c|c|c|}
\hline & Total water yield $(\mathbf{m m})$ & $\begin{array}{c}\text { Surface (runoff) flow } \\
(\mathbf{m m})\end{array}$ & Baseflow (mm) \\
\hline Actual & 111.45 & 25.21 & 86.24 \\
\hline SWAT & 107.37 & 25.25 & 82.12 \\
\hline
\end{tabular}

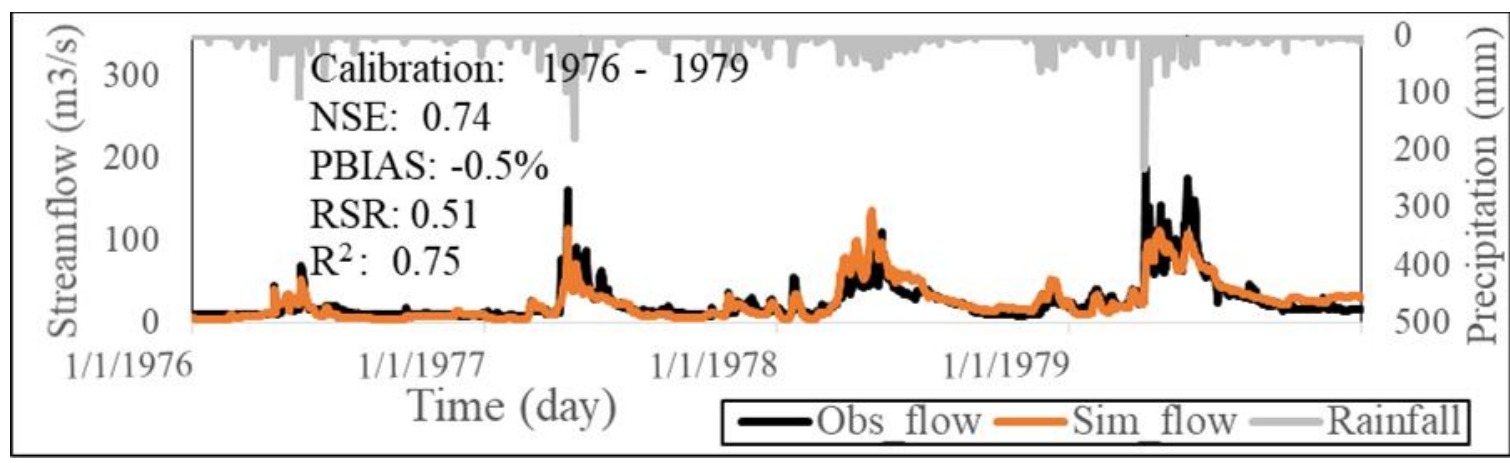

Figure 8: Calibration results (station IDD1 and 1985 land use map) from 1976-1979

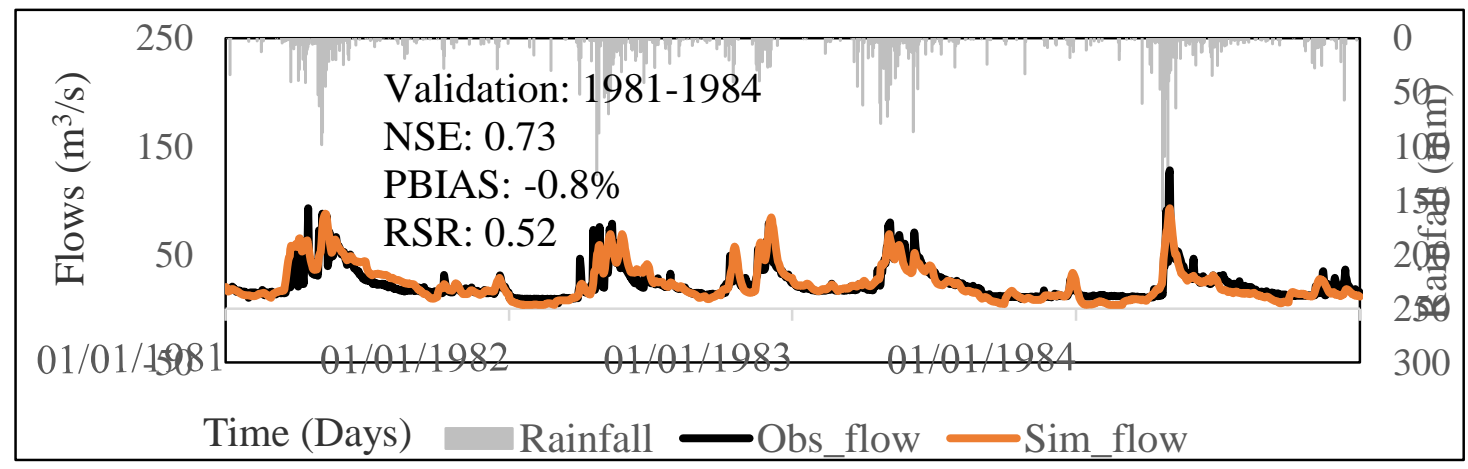

Figure 9: Validation results (station IDD1 and 1985 land use map) from 1981-1984 


\section{Impacts of Land Use/ Land Cover Change on Streamflow Values}

\section{Impacts of land-use change on mean annual flow, surface runoff, and baseflow}

Trend analysis of average annual streamflow simulated from year 1974 to 1985 from the SWAT model using 1985 (baseline), 2000, 2015, 2030 and 2050 land use maps indicated insignificant change. The percentage change, however, indicated an increase in average annual flow values. Between 1985 to 2000; 1985 to $2015 ; 1985$ to 2030 and 1985 to 2050 , the percentage increase in average simulated annual flow were $4.7 \%, 6.8 \%$, $12.6 \%$ and $19.3 \%$, respectively. The reason for the increase could be due to increased peak flow as surface runoff increases as a result of a decrease in the forest, shrubland and grassland, and the increase of built-up areas and cultivated land. These results are similar to the findings of some studies on land-use change impacts on streamflow worldwide (e.g. Piao et al., 2007; Tan et al., 2014). However, when comparing the trend in observed average annual flow it indicated a significant decreasing trend. The decreasing trend in observed flow data suggests that the impacts of rainfall decrease in the catchment outweigh the increased average annual flow due to landuse change.

The percentage of changes on surface runoff indicated increasing surface runoff. The past showed that surface runoff has increased from $25.2 \mathrm{~mm}$ (baseline) to 34.5 $\mathrm{mm}(36.9 \%)$ and to $36.2 \mathrm{~mm}(42.4 \%)$ for 2000 and 2015 land use/cover maps, respectively. Future surface runoff is expected to increase to $41.4 \mathrm{~mm}(64.3 \%)$; and to $47.6 \mathrm{~mm}(88.9 \%)$ for 2030 and 2050 land use/cover maps, respectively. The reason for increased surface runoff could be due to the fact that large areas of forest, shrubland, and grassland in the study area have been transformed into cultivated land and urban or built-up areas. It has been reported that in vegetation cover areas, the infiltration rate is higher than that of bare land (Tan et al., 2014). This is because as vegetation cover decreases, the soil surface layer is altered also, hence making the movement of water in the soil difficult (i.e. retarding infiltration rate). As the infiltration rate decreases surface runoff increases.

In the past, base flow indicated marginal or minimal decrease from $82.2 \mathrm{~mm}$ for 1985 (baseline) land use map to $79.1 \mathrm{~mm}$ ($3.8 \%)$ and to $77.8 \mathrm{~mm}(-5.4 \%)$ for 2000 and 2015 land use/cover maps, respectively. Future base flow is expected to decrease to $75.4 \mathrm{~mm}(-8.3 \%)$ and to $73.9 \mathrm{~mm} \mathrm{(-10.1 \% )} \mathrm{for} 2030$ and 2050 land use/cover maps, respectively. The minimal decrease in base flow at the analysed station IDD1 located below natural springs could be due to the presence of Rundugai natural springs. These springs were modelled as a point source in this study with a constant discharge. Figure 10 shows the impacts of land change mean annual flow, surface runoff, and baseflow in terms of the percentage change.

\section{Impacts of land-use change on high flow (Q5) and low flow (Q95)}

Trend analysis in the high flow (Q5) index indicated a insignificant increasing trend. The increase in high flow peaks could be a result of increased surface runoff as a result of a decrease in the forest, shrubland and grassland, and an increase in built-up areas and cultivated land. However, when comparing the trend in observed data it indicated an insignificant decreasing trend. This decreasing trend of Q5 in observed flow suggests that rainfall decrease in the catchment outweighs the increased high flow (Q5) due to land-use change. Analysis of low flow (Q95 index) indicated no changes as revealed by Munishi et al. (2009). Figure 11 shows 
changes in high flow (Q5) and low flow (Q95) for the period 1974-1985 simulated from 1985, 2000, 2015, 2030 and 2050 LULC maps.

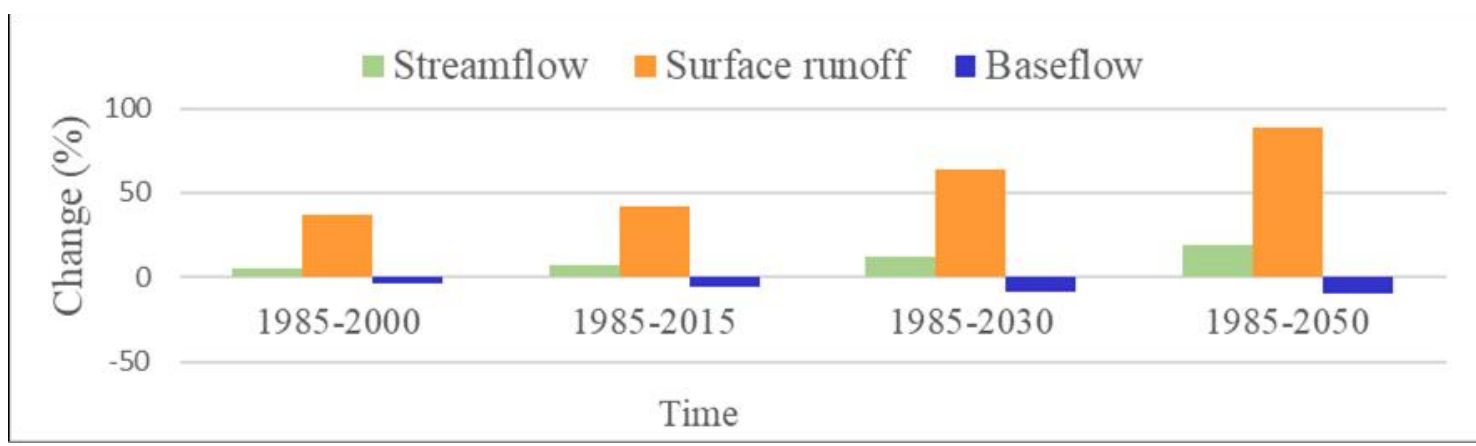

Figure 10: Impacts of land change on streamflow, surface runoff, and base flow

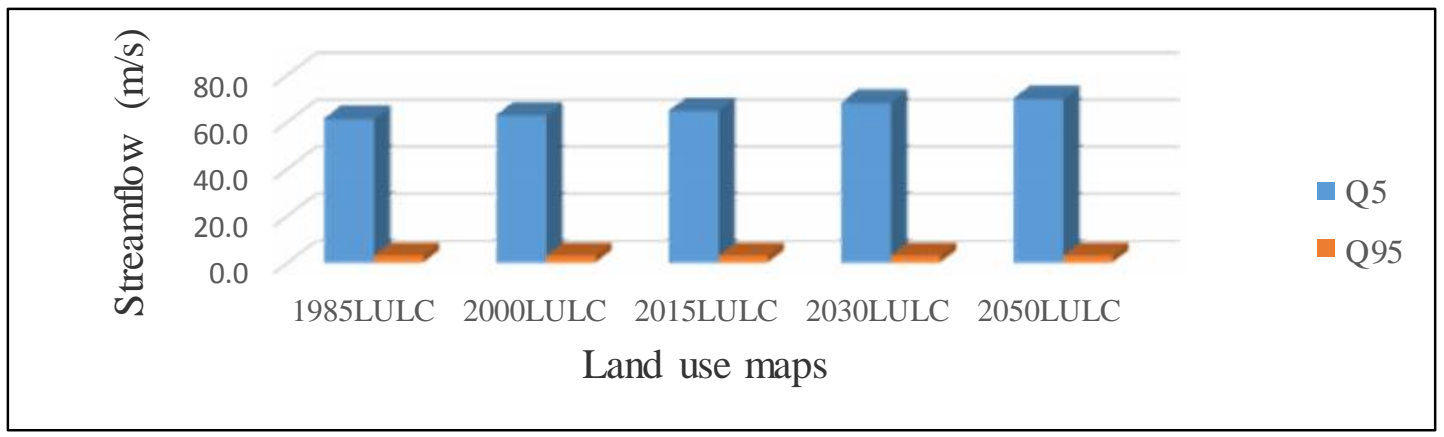

Figure 11: Changes in high flow (Q5) and low flow (Q95) for the period $1974-1985$ simulated with 1985, 2000, 2015, 2030 and 2050 LULC maps

\section{CONCLUSIONS}

SWAT model has shown its capability in assessing LULCC impacts on streamflow in Kikuletwa Catchment of Pangani River basin as demonstrated in this study. The statistical performance of SWAT model during calibration were $0.74,0.75,0.51$ and $-0.5 \%$ for NSE, R ${ }^{2}$, RSR and PBIAS, respectively and; for validation were 0.73 , $0.78,0.52$ and $-0.8 \%$ for NSE, $\mathrm{R}^{2}$, RSR and PBIAS, respectively. The findings of land change analysis revealed that, in Kikuletwa catchment from 1985 to 2000 , 1985 to 2015,1985 to 2030 and 1985 to 2050 the percentage $(\%)$ area change in cultivated land is $+21.1 \%,+29.2 \%$, $+38.2 \%$ and $+42.7 \%$, respectively; forest is $-2.3 \%,-3.1 \%,-3.8 \%$ and $-5.8 \%$, respectively, shrubland is $-6.3 \%,-10 \%$, $15.7 \%$ and $-16 \%$, respectively etc. The results from SWAT model used to assess the impact of LULCC indicated that, from 1985 to 2000,1985 to 2015,1985 to 2030 and 1985 to 2050, surface runoff increased from $25.2 \mathrm{~mm}$ (baseline) to $34.5 \mathrm{~mm}$ (36.9\%), $36.2 \mathrm{~mm} \mathrm{(42.4 \% ),} 41.4 \mathrm{~mm}$ $(64.3 \%)$ and $47.6 \mathrm{~mm}$. (88.9\%), respectively; while baseflow decreased marginally from $82.2 \mathrm{~mm}$ for 1985 (baseline) to $79.1 \mathrm{~mm}(-3.8 \%), 77.8 \mathrm{~mm}$ ($5.4 \%), 75.4 \mathrm{~mm}(-8.3 \%)$ and $73.9 \mathrm{~mm} \mathrm{(-}$ $10.1 \%)$, respectively. For extreme events, a high flow index (Q5) indicated an insignificant increasing trend and low flow (Q95) index indicated no change.SWAT model performed well in Kikuletwa catchment of the Pangani River basin, Tanzania. However, the model underestimated high peaks as it could not capture the high peaks. This could have affected simulated flow since the observed and simulated flow has not perfectly 
matched, and this should be addressed in future studies. Another setback was that rainfall gauging stations in the catchment are not spatially distributed. This could also have affected simulated flow. To have a good spatial representation of rainfall stations in the study area and of long records, the study recommends rehabilitation of non-operating rainfall stations and the collection of more rainfall data. This will improve the model performance during calibration and hydrological simulations in future investigations.

\section{CONFLICT OF INTEREST}

No conflict of interest in this article. This work is part of Ph.D. study 'Streamflow Perturbation in the Kikuletwa River Catchment of Pangani River Basin in Northern Tanzania: Impacts of Anthropogenic Activities and Climate Variability/Change' of the first author, upon which this paper is based.

\section{ACKNOWLEDGEMENT}

African Development Bank (AfDB) through the Ministry of Education of Tanzania is thanked for the financial support extended to the first author.

\section{REFERENCES}

Arnold J.G., Srinivasan R., Muttiah R.S. and Williams J.R. (1998). Large Area Hydrologic Modeling and Assessment, Part I: Model Development. Journal of American WRA 34: 73-89. http://dx.doi.org/10.1111/j.17521688.1998.tb05961.x.

Amini A., Ali T.M., Ghazali A.H.B., Aziz A.A. and Akib S.M. (2011). Impacts of land-use change on streamflow in the Dayanara Watershed, Malaysia. Arabian Journal for Science and Engineering, 36(5): 713-720. DOI: $10.1007 / \mathrm{s} 13369-011-0075-3$
Brown A.E., Western A.W., McMahon T.A. and Zhang L. (2013). Impact of forest cover changes on annual streamflow and flow duration curves. Journal of Hydrology, 483, 39-50. DOI: $10.1016 /$ j.jhydrol.2012.12.031

Chawla I. and Mujumdar P.P. (2015). Isolating the impacts of land use and climate change on streamflow. Hydrol. Earth Syst. Sci., 19, 3633-3651, DOI: 10.5194/hess-19-3633-2015.

Chiwa R. (2012). Effects of LULCCs on the hydrology of Weruweru-Kiladeda sub-catchment in the Pangani river basin, Tanzania. MSc. Thesis, Kenyatta University, Kenya.

Ficklin D.L., Stewart I.T. and Maurer E.P. (2013). Effects of projected climate change on the hydrology in the Mono Lake Basin, California. Climatic Change 116 (1), 111-131. DOI:10.1007/s10584-012-0566-6.

Gassman P.W., Reyes M.R., Green C.H. and Arnold J.G. (2007). The Soil and Water Assessment Tool: historical development, applications, and future research directions. T ASABE; 50(4): 1211-50.

Global Weather Data for SWAT. Available online at http://swat.tamu.edu/. Retrieved on $11^{\text {th }}$ November 2018.

Guzha A., Rufino M., Okoth S., Jacobs S. and Nóbrega R. (2018). Impacts of LULCC on surface runoff, discharge, and low flows: Evidence from East Africa. Journal of Hydrology: Regional Studies, 15: 49-67. https://doi.org/10.1016/j.ejrh.2017.11.0 05

Hemp A. (2005). Climate change-driven forest fires marginalize the ice cap wasting on Mt. Kilimanjaro. Glob. Change Biol. 11: 1013 - 1023.

Hemp A. (2006). Continuum or zonation? Altitudinal gradients in the forest vegetation of Mt. Kilimanjaro. Plant Ecol. 184: 27-42. https://doi.org/10.1007/s11258-0059049-4 
Hemp A. (2009). Climate change and its impact on the forests of Kilimanjaro. African Journal of Ecology, 47(Suppl. 1): $\quad 3-10$. DOI: $10.1111 / \mathrm{j} .1365-$ 2028.2008.01043.x

IPCC (Intergovernmental Panel for Climate Change) (2001). The Scientific Basis. Contribution of Working Group I to the Third Assessment Report Cambridge University Press, Cambridge, United Kingdom, and New York, NY, USA.

IPCC (Intergovernmental Panel for Climate Change) (2007). World Meteorological Organization (WMO) Guide to climate Change Practice. World Meteorology. Organization general Publisher, New York, USA.

Khoi D.N. and Suetsugi T. (2014). Impact of climate and land-use changes on hydrological processes and sediment yield: a case study of the Be River catchment, Vietnam, Hydrological Sciences Journal, 59(5): 1095-1108, DOI: $10.1080 / 02626667.2013 .819433$.

Kendall M.G. (1975). Rank Correlation Methods. 4th Edition, Charles Griffin, London. 202p.

Lalika M.C.S., Meire P., Ngaga Y.M. and Changa' L. (2014). Understanding Watershed Dynamics and Impacts of Climate Change and Variability in the Pangani River Basin, Tanzania Hydrological Sciences Journal, 59(5): 1095-1108. DOI:10.1080/ 02626667.2013.819433.

Lambin E.F., Turner B.L., Geist H., Agbola S. and Angelsen A. (2001). The causes of land-use and land-cover change: moving beyond the myths. Global Environmental Change, 11(4): 261-69.

Lambin E.F., Geist H. and Lepers E. (2003). Dynamics of land use and cover change in tropical regions. Annual Review of Environment and Resources 28:

205-241. https://doi.org/10.1146/annurev.energy. 28.050302.105459
Li Z., Liu W.Z., Zhang X.C. and Zheng F.L. (2009). Impacts of land-use change and climate variability on hydrology in an agricultural catchment on the Loess Plateau of China, J. Hydrol., 377: 3542, DOI: $10.1016 /$ j.jhydrol.

Lørup J.K., Refsgaard J.C. and Mazvimavi D. (1998). Assessing the effect of landuse change on catchment runoff by the combined use of statistical tests and hydrological modelling: Case studies from Zimbabwe, Journal of Hydrology, 205:

147-163,

DOI:10.1016/S01681176(97)00311-9.

Lu D. and Weng Q. (2007). A survey of image classification methods and techniques for improving classification performance. International Journal of Remote Sensing, 28(5): 823-870. https://doi.org/10.1080/0143116060074 6456.

Mann H.B. (1945). Non-parametric tests against trend. The Econometric Society, 13: 245-259. DOI: 10.2307/1907187

Missana S.B., Majule A.E. and Lyaruu H.V. (2003). Linkages between Changes in Land Use, Biodiversity and Land Degradation on the slopes of Mount Kilimanjaro, Tanzania. Land Use Change Impacts and Dynamics (LUCID). International Livestock Research Institute, Nairobi.

Moriasi D.N., Arnold J.G., van Liew M.W., Binger R.L., Harmel R.D. and Veith T. (2007). Model evaluation guidelines for systematic quantification of accuracy in watershed simulations. Transactions of the ASABE, 50(3): 885-900. doi: 10.13031/2013.23153

Mulungu D.M.M., and Kashaigili J.J. (2012). Dynamics of LULCCs and implications on river flows in Simiyu River catchment, Lake Victoria Basin in Tanzania. The Nile Basin Water Science and Engineering Journal, 5(2): 23-35.

Mulungu D.M.M. and Munishi S.E. (2007). Simiyu River catchment parameterization using the SWAT 
model, Journal of Physics and Chemistry of the Earth, Parts $\mathrm{A} / \mathrm{B} / \mathrm{C}$, 32(15-18): $1032-1039$.

Munishi K.T., Hermegast A.M. and Mbilinyi B.P. (2009). The impacts of changes in vegetation cover on dry season flow in the Kikuletwa River, northern Tanzania. African Journal of Ecology, 47(Suppl. 1): 84-92. DOI: 10.1111/j.1365-2028.2008.01083.x

Munishi L.K. and Sawere P.C. (2014). Climate change and decline in water resources in Kikuletwa Catchment, Pangani, Northern Tanzania. African Journal of Environmental Science and Technology, 8(1): 58-65, DOI: 10.5897/AJEST2013.1597.

Ndomba P.M., Mtalo F. and Killingtveit A. (2008). SWAT model application in a data-scarce tropical complex catchment in Tanzania, Journal of Physics and Chemistry of the Earth, 33: 626-632.

Neitsch S.L., Arnold J.G., Kiniry J.R., Williams J.R. and King K.W. (2002). Soil and Water Assessment Tool, Theoretical documentation Version 2000, Texas Water Resources Institute, College Station, TWRI Report TR192.

Ngana J.O. (2002). Diminishing water resources and increasing water demands. In: Water Resources Management. The Case of Pangani River Basin, Issues and Approaches (Ed. J.O. Ngana) Dar es Salaam University Press, Tanzania.

Nobert J. and Jeremiah J. (2012). Hydrological response of watershed systems to land use/land cover change: A case of Wami River basin. The Open Hydrology Journal, 6: 78-87. DOI: $10.2174 / 1874378101206010078$

PBWO/IUCN (2006). Hydrology and System Analysis Volume 1 of 2. The Hydrology of the Pangani River Basin. Report 1: Pangani River Basin Flow Assessment Initiative, Moshi, $62 \mathrm{p}$.

PBWO/IUCN (2008). Basin Delineation Report. Pangani Basin Water Board, Moshi and IUCN Eastern and Southern
Africa Regional Programme, Nairobi. $57 \mathrm{p}$.

Piao S., Friedlingstein P., Ciasis P., de Noblet-Ducoudre N., Labata D., and Zaehle S. (2007). Changes in climate and land use have a larger direct impact than rising $\mathrm{CO}_{2}$ on global river runoff trends, Proceedings of the National Academy of Sciences of the United States of America, 104: 15242-15247. https://doi.org/10.1073/pnas.070721310 4

Røhr P.C. and Killingtveit A. (2002). Study of two catchments on the hillside of Mt Kilimanjaro. Water Resources Management: The Case of Pangani River Basin. Issues and Approaches (Ed. J.O. Ngana) Dar es Salaam University Press, Tanzania.

Sarmett J.D. and Faraji S.A. (1991). The hydrology of Mount Kilimanjaro: an examination of dry season runoff and possible factors leading to its decreases, In: The Conservation of Mount Kilimanjaro. (Ed. W.D. Newmark) IUCN, Gland, Switzerland.

Shaghude Y.W. (2006). Review of water resource exploitation and land-use pressure in Pangani River Basin, Tanzania. Western Indian Ocean Marine Science Association Journal, 5(2): 195-207.

Shishira E.K. (2002). Land-use changes and sustainability of water resources utilization in the Pangani river basin downstream of the Nyumba ya Mungu dam. In: Water Resources Management. The Case of Pangani River Basin, Issues and Approaches (Ed. J.O. Ngana) Dar es Salaam University Press, Tanzania.

Stehman S.V. (2009). Sampling designs for accuracy assessment of land cover', International Journal of Remote Sensing, 30(20): 5243-5272. https://doi.org/10.1080/0143116090313 1000

Tan L.M., Ibrahim L.A., Yusop Z., Duan Z. and Ling L. (2014). Impacts of landuse and climate variability on 
hydrological components in the Johor River basin, Malaysia, Hydrological Sciences Journal, 60(5): 873-889, DOI: $10.1080 / 02626667.2014 .967246$.

Valimba P. (2008). Temporal Flow Variations: A Challenge for Surface Water Management in Tanzania, World Water Congress, Montpellier, France.

Wei X.H., Liu W.F. and Zhou P.C. (2013). Quantifying the relative contributions of forest change and climatic variability to hydrology in large watersheds: A critical review of research methods. Water, 5: 728-746. DOI:10.3390/w5020728.

Yanda P.Z. (2002). Land-use pressure on the upper slopes of Mount Kilimanjaro and progressive colonization of marginal areas on foot slopes. In: Water Resources Management. The Case of Pangani River Basin, Issues and Approaches (Ed J.O. Ngana) Dar es Salaam University Press, Tanzania.

Yanda P.Z. and Shishira E.K. (1999). Forest Conservation and Resource Utilization on Southern Slopes of Mount Kilimanjaro: Trends, Conflicts, and Resolutions. Dar es Salaam: Dar es Salaam University Press, Tanzania.

Yanda P.Z. and Munishi P.K.T. (2006). Hydrologic and land use/cover change analysis for the Ruvu River (Uluguru) and Sigi river (East Usambara) watersheds for WWF/CARE Dar es Salaam, Tanzania. 